\title{
Re-emergence of syphilis in women of reproductive age and its association with the increase in congenital syphilis, the case of Mexico during the years 2010-2019
}

\author{
Santa García-Cisneros \\ Instituto Nacional de Salud Publica \\ Antonia Herrera-Ortiz \\ Instituto Nacional de Salud Publica \\ Maria Olamendi-Portugal \\ Instituto Nacional de Salud Publica \\ Miguel A. Sanchez-Aleman ( $\square$ msanchez@insp.mx ) \\ Instituto Nacional de Salud Publica https://orcid.org/0000-0003-2383-7930
}

\section{Research Article}

Keywords: Syphilis, Congenital, Syphilis, Sexually Transmitted Diseases, Mexico

Posted Date: June 17th, 2021

DOI: https://doi.org/10.21203/rs.3.rs-607054/v1

License: (c) (1) This work is licensed under a Creative Commons Attribution 4.0 International License.

Read Full License 


\section{Abstract}

\section{Background}

Syphilis is a sexually transmitted infection that is re-emerging in different parts of the world. This infection can be transmitted during pregnancy causing neonatal syphilis. The objective of the study was to determine the trend of syphilis, congenital syphilis, and mortality from congenital syphilis among the Mexican population between the years 2010-2019.

\section{Methods}

We formed databases about the incidence of syphilis, the incidence of congenital syphilis, cases of congenital syphilis, and deaths of congenital syphilis using information from the Morbidity and Mortality Yearbooks and the Bulletin of the Mexican Ministry of Health, considering age, sex, the states of Mexico, and year. The trend was analyzed using linear regression, the increase was estimated with $95 \%$ confidence intervals, and $p<0.05$ was considered statistically significant.

Results

The incidence of syphilis increases on average 0.336 cases $/ 100,000$, being higher among women aged $15-19$ years ( 0.693 cases). Congenital syphilis has grown, from 62 cases in the year 2010 to 372 cases in the year 2019; the cases of congenital syphilis have relation to the increase of syphilis among women aged 20-24 years. Fifty percent of the states of Mexico without cases of congenital syphilis in 2010, but only $10 \%$ in 2018 . Between the years 2010 to 2017,62 deaths from congenital syphilis were reported.

\section{Conclusion}

Congenital syphilis is increasing in Mexico, as a consequence of the reemergence of syphilis among the population of reproductive age, it is necessary to attend to syphilis in various population groups.

\section{Background}

Syphilis is a sexually transmitted infection (STI) caused by the bacterium Treponema pallidum subs pallidum. Syphilis had four stages, the primary stage begins with the chancre which appears on the glans, penis, labia majora, labia minora, the perineum, or extragenital regions (palate, anus, rectus, fingers, or tongue). ${ }^{1}$ The secondary syphilis is characterized by the systemic bacterial spread, erythematous rashes appear on palms of hands, soles of feet, chest, and back. Later there is a latency phase, without any clinical manifestation, but the non-treponemal serological tests remain positive, this stage can last up to 20 years. The infection continues and the tertiary stage is developed, affecting cardiovascular, nervous, and musculoskeletal systems. ${ }^{1-3}$ T. pallidum can traverse the placental barrier, causing congenital syphilis. About $50 \%$ of pregnant women infected with T. pallidum and not treated, transmit syphilis to their child before birth. Among people living with HIV the natural history of syphilis is altered, 
there are more cases with tertiary syphilis, and the cases are found in a shorter time, and the presence of syphilis increases the transmission of HIV. ${ }^{4,5}$.

According to the World Health Organization (WHO) in 2016, the incidence of curable STIs in the world was estimated at 376.4 million new cases among people aged 15 to 49 years, of which 6.3 million correspond to syphilis, resulting in a worldwide incidence of 1.5 cases per 1000 inhabitants and 2.0 cases per 1000 inhabitants in America. ${ }^{6}$ Furthermore, syphilis caused 200,000 stillbirths and deaths worldwide, making it one of the leading causes of newborn deaths. In the Americas region, an estimated 22,800 cases of mother-to-child transmission of syphilis were estimated, with a rate of 1.7 cases per 1,000 live births. ${ }^{7}$ In Mexico, an increase in the incidence of syphilis was detected between 2003 and 2013, concentrating among men aged 20-24 years and $25-44$ years. ${ }^{8}$ The objective of this study was to determine the trend of syphilis and congenital syphilis in Mexico, between the years 2010 to 2019, through the information available in the General Directorate of Epidemiology of the Ministry of Health of Mexico.

\section{Methods}

We review the information about the incidence of syphilis, the incidence of congenital syphilis, and cases of congenital syphilis from the Morbidity Yearbooks of the General Directorate of Epidemiology of the Ministry of Health from the year 2010 to 2019. Databases were formed with syphilis information and age, sex, year, and states of Mexico variables. A second database was formed, using the number of infant deaths, the year, and the state of Mexico, with information from the Morbidity and Mortality Yearbooks and the Bulletin of the Ministry of Health.

The trend analysis of syphilis incidence among women, syphilis incidence among men, and congenital syphilis, from 2010 to 2019 , evaluated the average change through linear regression, with $95 \%$ confidence intervals $(95 \% \mathrm{Cl})$. Subsequently, with the t-student test for slopes, the trends by age groups stratified by sex were evaluated, it was considered statistically significant $p<0.05$.

The number of cases of congenital syphilis was stratified into $0-2$ cases, $3-10$ cases, $11-20$ cases and 21 or more cases, a comparison was made between the years 2010 and 2019 considering each state of the republic. Subsequently, the information on mortality from congenital syphilis was analyzed, with information on the year of the report and status.

Finally, the correlation between trends in congenital syphilis cases and incidence of syphilis in women aged 15-19 years and 20-24 years was evaluated, as well as the correlation between incidence of congenital syphilis and incidence of syphilis among women aged 20-24 years. for each state of the republic, using the Spearman correlation test. The tests were statistically significant with $p<0.05$, all analyzes were carried out with the statistical program Graph Pad 10.0

\section{Results}


The highest incidence of syphilis in the general population was observed in 2019 with 6.09 cases per 100,000 inhabitants, compared to 2.03 cases in 2010, with an average annual increase of 0.336 cases per 100,000 inhabitants $\left(\mathrm{Cl}_{95 \%} 0.180-0.492, \mathrm{p}=0.001\right)$. Since 2012 , men had a higher incidence of syphilis than women; the average increase among men was 0.482 cases per 100,000 inhabitants $\left(\mathrm{Cl}_{95 \%}\right.$ $0.303-0.660, p<0.001)$, compared to the increase among women that was 0.178 cases per 100,000 inhabitants $\left(\mathrm{Cl}_{95 \%} 0.017-0.339, \mathrm{p}=0.034\right)$, this difference was statistically significant $(\mathrm{p}=0.010)$. An increase of congenital syphilis was observed, a rate of 2.93 per 100,000 newborns in the year 2014, up to 17.28 in the year 2019 , with an average annual increase of 1.693 per 100,000 newborns $\left(\mathrm{Cl}_{95 \%} 0.986-\right.$ 2.394, $\mathrm{p}<0.001)$, as shown in Fig. 1.

Among women, the highest incidence occurred in the 20-24 years-old group with 16.77 cases per 100,000 inhabitants in 2019 and an annual increase of 0.438 per 100,000 inhabitants (CI95\% 0.062$0.813 ; p=0.028$ ), followed by $15-19$ years-old group with an incidence of 12.7 cases per 100,000 inhabitants in 2019 and an average annual increase of $0.693\left(\mathrm{Cl}_{95 \%} 0.191-1.194 ; \mathrm{p}=0.012\right)$. Among men, the increase in incidence was concentrated in the 20-24-year-old group with a rate of 14.89 cases per 100,000 inhabitants in 2019 , with an annual increase of 0.786 per 100,000 inhabitants $\left(\mathrm{Cl}_{95 \%} 0.653-\right.$ $1.505 ; p<0.001$ ), followed by the group of $25-44$ years with an incidence of 13.93 cases per 100,000 in 2019 , with an annual increase of 0.991 cases per $100,000\left(\mathrm{Cl}_{95 \%} 0.462-1.521, \mathrm{p}=0.002\right)$, as shown in Fig. 2.

We reported a constant increase of new cases of congenital syphilis, 62 cases in the year 2010, 83 cases in the year 2015, and 372 cases in the year 2019. The states with the highest number of congenital syphilis cases in 2010 were Baja California, Colima, Chihuahua, Nuevo León, and Sonora, which reported between 6 and 17 cases; while in the year 2019 Baja California, Jalisco, Sinaloa, Sonora, and Tamaulipas presented between 20 and 79 cases of congenital syphilis. In addition, of the 32 states of Mexico, 16 did not report congenital syphilis cases in 2010 , on the other hand, three states did not report congenital syphilis cases in 2019. The states of Campeche, Hidalgo, Morelos, Oaxaca, and Tlaxcala were two or fewer congenital syphilis cases from 2010 to 2019, as shown in Fig. 3.

The number of cases of congenital syphilis was correlated with the incidence of syphilis among women from 2010 to $2019\left(r^{2}=0.787, p<0.001\right)$, however, this correlation is higher when stratifying by age. Among women aged 15-19 years, each increase in an incidence unit showed an average increase of 36 new cases of congenital syphilis (slope $36.1, \mathrm{Cl}_{95 \%} 26.5-45.8, \mathrm{r}^{2}=0.904 ; \mathrm{p}<0.001$ ); among the group of women aged 20-24, this increase was an average of 30 cases per year (slope $30.4, \mathrm{Cl}_{95 \%} 24.8-36.0, \mathrm{r}^{2}=$ $0.952 ; p<0.001)$, as shown in Fig. 4. The correlation between syphilis and congenital syphilis by state of the Mexican Republic was evaluated, the information from 2019 of women aged 20-24 years was used, finding an $r^{2}=0.621 ; p<0.001$. The seven states that reported an incidence of congenital syphilis greater than 40 cases per 100,000 live births are the same states that presented an incidence of syphilis greater than 40 cases per 100,000 women. States such as Morelos and Quintana Roo, reported a higher incidence of syphilis and a lower incidence of congenital syphilis, in contrast, states such as San Luis 
Potosí, Tabasco and Veracruz, reported a higher incidence of congenital syphilis and a lower incidence of acquired syphilis, such as shown in Fig. 5.

The general mortality due to congenital syphilis in children under 1 year of age in Mexico was 0.02 per 100,000 children for the year 2012, and 0.01 for the years 2015, 2016, and 2017; for the years 2010, 2011, 2013 , and 2014 we did not find information. In the review of deaths from congenital syphilis, 62 deaths were found between the years 2010 to 2017, the lowest number being in the years 2010 ( 5 deaths) and 2014 (1 death) and the highest in the years 2011 (10 deaths), 2015 (12 deaths) and 2017 (10 deaths). Considering the total number of deaths between 2010 and 2017 by state, the states of Baja California (7), Chihuahua (5), Jalisco (6), Sinaloa (5) and Veracruz (5), are those that presented the highest number of deaths, in contrast the states of Baja California Sur, Campeche, Guerrero, Hidalgo, Puebla, Quintana Roo, San Luis Potosí, Tlaxcala, Yucatán and Zacatecas, did not report any death from congenital syphilis during the period analyzed.

\section{Discussion}

According to the latest WHO estimates, the frequency of syphilis has remained constant between 2012 and 2016 with a prevalence of $0.5 \%$, both in men and women worldwide, however, in the Americas region it was reported an increase from $0.7-0.9 \%$ in both women and men. ${ }^{6}$ The increase in syphilis has been documented among men who have sex with men and among people living with HIV in different parts of the world. ${ }^{9-10}$ In Mexico, an increase in syphilis was reported among young men between 2003 and 2013, it was hypothesized that they could be men who have sex with men, because at that time, an increase in syphilis among women had not been reported, nor an increase in congenital syphilis. ${ }^{8}$ With the results of the present study, it is observed that the increase in syphilis among men continues, in addition, there is an increase of more than double in the incidence of syphilis among women, as well as a great increase in cases of congenital syphilis, 6 times more cases.

The increase in syphilis cases among women occurs mainly in those of reproductive age, so the risk of transmission of $T$. pallidum during pregnancy increases, resulting in a greater number of cases and deaths from congenital syphilis. ${ }^{11}$ PAHO in 2009 proposed the Elimination of Maternal-Child Transmission of syphilis and HIV, later adding Chagas disease and hepatitis B. $1^{2,13}$ One of the goals is to reduce the incidence of congenital syphilis to 0.5 or less per 1,000 live births $(0.005$ per 100,000 live births); in current study, a lower rate of congenital syphilis was observed, however, the number of cases of congenital syphilis increased, from 62 cases in 2010 to 372 cases in 2019. Furthermore, in Mexico there is a lack of information about stillbirths due to T. pallidum, so the real incidence of congenital syphilis is underestimated. ${ }^{14}$

To maintain the goal of reducing congenital syphilis, one of the main recommendations is to have $95 \%$ coverage of syphilis screening in pregnant women and $95 \%$ of treatment. ${ }^{13}$ However, this percentage of coverage is far from being achieved in Mexico, according to data from National Surveys (ENSANUT-2012 and ENSANUT-2018), ${ }^{15,16}$ only $43.6 \%$ of teenagers reported that they were tested for syphilis during their 
pregnancy, increasing to $56 \%$ in 2018 , while in women aged $20-49$ years, the syphilis test report increased from 39.9-62.5\%. An increase in tests for syphilis during pregnancy should lead to a decrease in the number of cases of congenital syphilis, however, it is unknown whether women had access to treatment. ${ }^{14}$ Syphilis screening during pregnancy is very important, so changes and updates to the Official Mexican Standards, as well as the Clinical Guidelines, must be considered. ${ }^{17}$

Young people had a greater increase in syphilis, in women it was the 15-24-year-old groups that had the highest rates, while among men it was presented in the 20-44-year-old groups. In the United States, it was reported that $45 \%$ of incident STI cases are concentrated in the population aged $15-24$ years. ${ }^{18}$ It is during this stage that sexual life begins and they experiment with the use of illegal drugs, in addition to low condom use has been reported. It is necessary to continue with the emphasis of STI prevention programs in this population group.

There is a great heterogeneity in the frequency of syphilis in the states of the Mexican Republic, some with a directly proportional correlation between syphilis and congenital syphilis, other states do not present an apparent correlation. Further research is needed to determine the reason for these differences, which may be at the biological level (immune status, circumcision, ectopy, coinfections), lifestyle (number of sexual partners, concurrent partners, characteristics of the partner, condom use, sexual practices and seeking medical attention), at the population level (place of residence, access to services, prevention programs, quality of care, prevalence of STIs in the locality) or characteristics of social structure (social class, age, sex or ethnicity). ${ }^{19}$ All these variables possibly participate in the great variation of syphilis and congenital syphilis in Mexico, similar to that reported for the Herpes Simplex Virus type 2, a seroprevalence of $5.5 \%$ in the western region (Colima, Jalisco, Michoacán, Nayarit) up to $15.5 \%$ in the southwest (Chiapas, Guerrero and Oaxaca). ${ }^{20}$

\section{Conclusions}

There is an increase in syphilis among different population groups and it is concentrated in the young population of reproductive age, which cause an increase in the number of cases of congenital syphilis. Its necessary strengthened different programs, such as early detection of syphilis, treatment and follow-up of the diagnosed persons and trace of contacts, to help reduce this public health problem.

\section{Abbreviations}

\section{STI}

sexually transmitted infection.

HIV

Human immunodeficiency virus

WHO

World Health Organization

$95 \% \mathrm{Cl}$ 
$95 \%$ confidence intervals

\section{Declarations}

Ethics approval and consent to participate. Not applicable

Consent for publication. Not applicable

Availability of data and materials. The datasets used during the current study are available from the corresponding author on reasonable request.

Competing interests. The authors declare that they have no competing interests.

Funding. Part of this project was carried out with the support of CONACyT SALUD-2017-1-290201

Authors' contributions. SGC construct datasets, analyzes the graphs and write manuscript. AHO analyzes the information and reviews the manuscript. MOL reviews the manuscript. MASA construct figures, statistical analyzes, and write the manuscript. All authors read and approved the final manuscript.

Acknowledgements. Not applicable

\section{References}

1. Peeling RW, Mabey D, Kamb ML, Chen XS, Radolf JD, Benzaken AS. Syphilis. Nat Rev Dis Primers. 2017;12:1-21.

2. Fonollosa A, Martinez-Indart L, Artaraz J, Martinez-Berriotxoa A, Agirrebengoa K, Garcia M, et al. Clinical manifestations and outcomes of syphilis-associated uveitis in northern Spain. Ocul Immunol Inflamm. 2016;24:147-52.

3. Syphilis. Hook EW 3. Lancet. 2017;389:1550-7. rd. .

4. Corti M, Palmieri O, Maronna E. Sífilis secundaria maligna, forma clínica rupioide, en una enferma VIH positiva. Rara presentación de la lúes secundaria: Presentación de un caso y revisión de la literatura. Rev Argen Dermatol. 2014;95:22-6.

5. Schmidt R, Carson PJ, Jansen RJ. Resurgence of Syphilis in the United States: An Assessment of Contributing Factors. Infect Dis. 2019;16:12:1178633719883282.

6. Rowley J, Vander Hoorn S, Korenromp E, Low N, Unemo M, Abu-Raddad LJ, et al. Chlamydia, gonorrhoea, trichomoniasis and syphilis: global prevalence and incidence estimates, 2016. Bull World Health Organ. 2019;97:548-62.

7. Kamb M, Schwartz-Benzaken A, Karem K, Matheu J, Pérez F. Orientación para el diagnóstico de la sífilis en América Latina y el Caribe: cómo mejorar la adopción, interpretación y calidad del diagnóstico en diferentes entornos clínicos. Washington: OPS/OMS, 2015; 32. 
8. Herrera-Ortiz A, Uribe-Salas FJ, Olamendi-Portugal M, García-Cisneros S, Conde-Glez CJ, SánchezAlemán MA. Análisis de la tendencia de sífilis adquirida en México durante el periodo 2003-2013. Salud Publica Mex. 2015;57:335-42.

9. Rowley J, Vander Hoorn S, Korenromp E, Low N, Unemo M, Abu-Raddad LL, Chico RM, Smolak A, Newman L, Gottlieb S, Thwin SS, Brouteta N, Taylor MM. Chlamydia, gonorrhoea, trichomoniasis and syphilis: global prevalence and incidence estimates, 2016. Bull World Health Organ. 2019;97:54862P.

10. Spiteri G, Unemo M, Mårdh O, Amato-Gauci AJ. The resurgence of syphilis in high-income countries in the 2000s: a focus on Europe. Epidemiol Infect. 2019;147:e143.

11. Galvis AE, Arrieta A. Congenital Syphilis: A U.S. Perspective. Children (Basel). 2020;7:203.

12. Organización Panamericana de la Salud. Iniciativa regional para la eliminación de la transmisión maternoinfantil de $\mathrm{VIH}$ y de la síflis congénita en América Latina y el Caribe: documento conceptual. Montevideo: CLAP/SMR; 2009.

13. Organización Panamericana de la Salud. ETMI-PLUS: marco para la eliminación de la transmisión maternoinfantil del VIH, la sífilis, la hepatitis y la enfermedad de Chagas. Julio del 2017. OPS/CHA/17 - 009.

14. Organización Panamericana de la Salud. Eliminación de la transmisión maternoinfantil del VIH y la síflis en las Américas. Actualización 2016. Washington, D.C.: OPS; 2017.

15. Gutiérrez JP, Rivera-Dommarco J, Shamah-Levy T, Villalpando-Hernández S, Franco A, Cuevas-Nasu L, et al. Encuesta Nacional de Salud y Nutrición 2012. Resultados Nacionales. Cuernavaca: Instituto Nacional de Salud Pública; 2012.

16. Shamah-Levy T, Vielma-Orozco E, Heredia-Hernández O, Romero-Martínez M, Mojica-Cuevas J, Cuevas-Nasu L, et al. Encuesta Nacional de Salud y Nutrición 2018-19: Resultados Nacionales. Cuernavaca: Instituto Nacional de Salud Pública; 2020.

17. Herrera-Ortiz A, López-Gatell H, García-Cisneros S, Cortés-Ortiz MA, Olamendi-Portugal M, HegewischTaylor J, et al. Sífilis congénita en México. Análisis de las normas nacionales e internacionales desde la perspectiva del diagnóstico de laboratorio. Gac Med Mexico. 2019;155:464-72.

18. Kreisel KM, Spicknall IH, Gargano JW, Lewis FM, Lewis RM, Markowitz LE, et al. Sexually Transmitted Infections Among US Women and Men: Prevalence and Incidence Estimates, 2018. Sex Transm Dis. 2021 Jan 23. doi: 10.1097/OLQ.0000000000001355.

19. Aral SO. Determinants of STD epidemics: implications for phase appropriate intervention strategies. Sex Transm Infect. 2002;78(Suppl 1):i3-13. Suppl 1(.

20. Sanchez-Aleman MA, Del Villar-Tapia YG, Gutierrez JP, Garcia-Cisneros S, Olamendi-Portugal ML, Herrera-Ortiz A, et al. Heterogeneity of Herpes Simplex Virus Type 2 Seroprevalence From a National Probability Survey In Mexico, 2012. Sex Transm Dis. 2018;45:111-7.

\section{Figures}




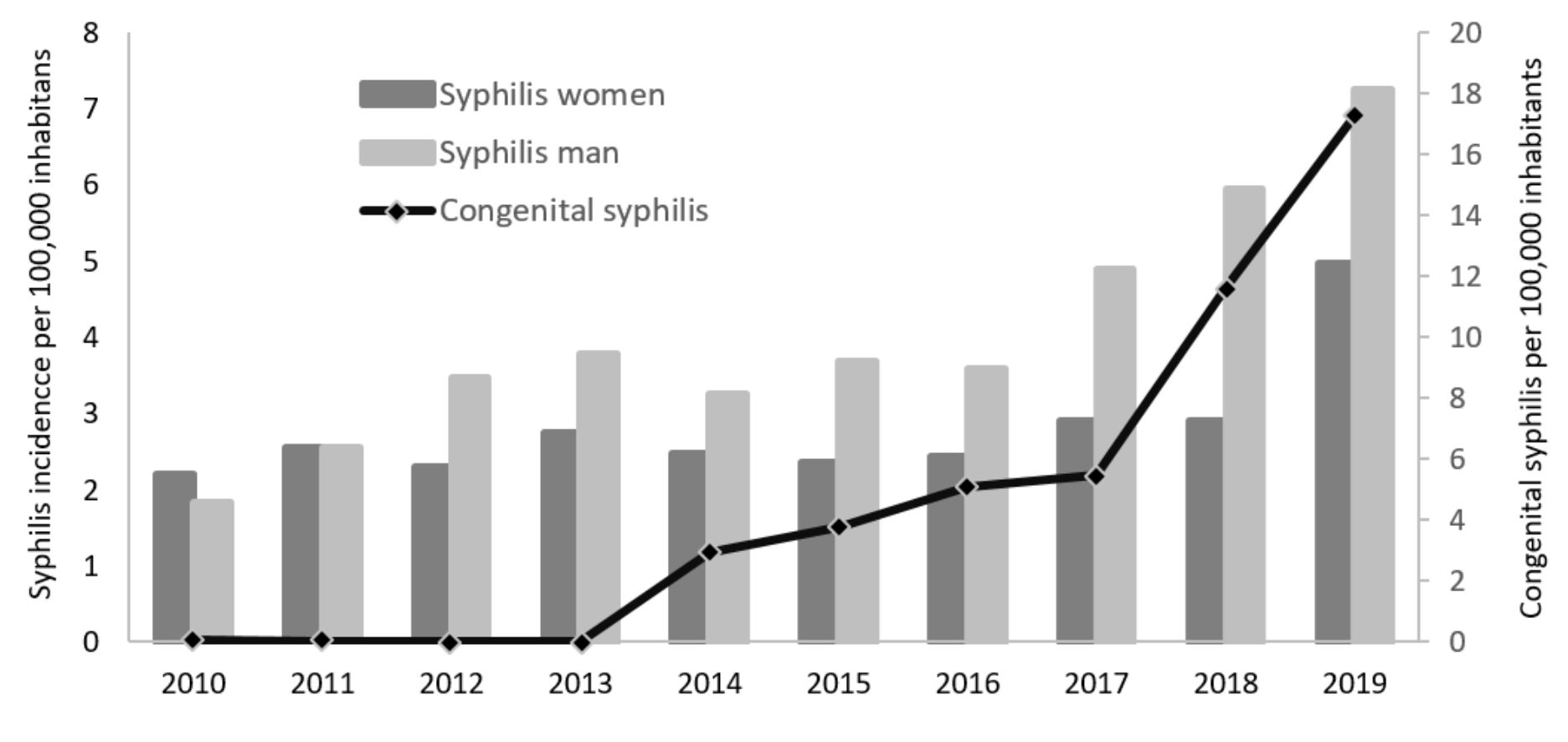

Figure 1

Syphilis incidence in Mexico, 2010-2019.

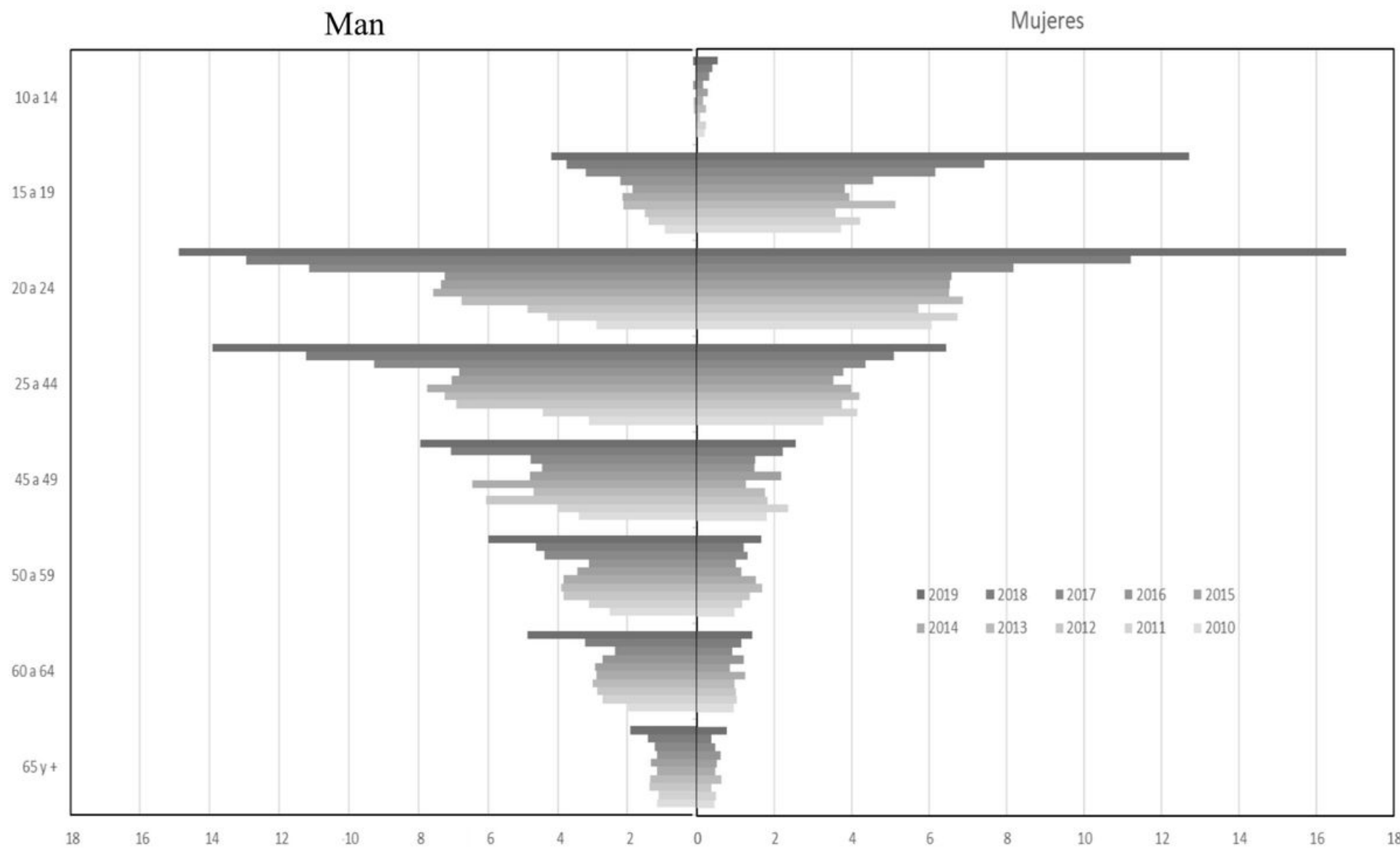


Figure 2

Syphilis incidence stratified by sex and age, Mexico 2010-2019.

\begin{tabular}{|l|r|r|r|r|r|r|r|r|r|r|}
\hline & 2010 & 2011 & 2012 & 2013 & 2014 & 2015 & 2016 & 2017 & 2018 & 2019 \\
\hline Aguascalientes & 0 & 0 & 0 & 0 & 0 & 0 & 3 & 5 & 5 & 16 \\
\hline Baja California & 17 & 20 & 8 & 12 & 15 & 24 & 38 & 30 & 24 & 79 \\
\hline Baja Cal.Sur & 0 & 1 & 0 & 0 & 1 & 1 & 1 & 8 & 3 & 9 \\
\hline Campeche & 1 & 0 & 0 & 0 & 0 & 0 & 0 & 0 & 1 & 0 \\
\hline Cohauila & 0 & 1 & 2 & 0 & 0 & 5 & 7 & 2 & 12 & 11 \\
\hline Colima & 6 & 3 & 1 & 0 & 0 & 0 & 1 & 1 & 3 & 6 \\
\hline Chiapas & 0 & 0 & 0 & 2 & 0 & 0 & 0 & 0 & 0 & 4 \\
\hline Chihuahua & 7 & 6 & 1 & 0 & 4 & 8 & 4 & 1 & 3 & 4 \\
\hline Cd.de México & 0 & 1 & 0 & 0 & 1 & 5 & 4 & 1 & 3 & 3 \\
\hline Durango & 0 & 0 & 0 & 0 & 5 & 4 & 4 & 2 & 4 & 11 \\
\hline Guanajuato & 1 & 1 & 4 & 1 & 1 & 1 & 0 & 3 & 5 & 6 \\
\hline Guerrero & 1 & 0 & 4 & 0 & 1 & 0 & 0 & 0 & 1 & 4 \\
\hline Hidalgo & 2 & 1 & 0 & 0 & 0 & 0 & 0 & 0 & 0 & 2 \\
\hline Jalisco & 3 & 2 & 1 & 3 & 0 & 1 & 0 & 0 & 40 & 57 \\
\hline México & 0 & 3 & 2 & 1 & 0 & 1 & 5 & 3 & 4 & 1 \\
\hline Michoacán & 0 & 0 & 0 & 0 & 0 & 0 & 4 & 1 & 1 & 6 \\
\hline Morelos & 0 & 2 & 0 & 0 & 2 & 0 & 0 & 0 & 1 & 1 \\
\hline Nayarit & 0 & 0 & 2 & 2 & 0 & 1 & 2 & 1 & 5 & 12 \\
\hline Nuevo León & 6 & 10 & 7 & 7 & 2 & 2 & 9 & 10 & 38 & 13 \\
\hline Oaxaca & 1 & 3 & 0 & 0 & 0 & 0 & 0 & 0 & 0 & 0 \\
\hline Puebla & 0 & 1 & 1 & 2 & 0 & 3 & 1 & 2 & 4 & 5 \\
\hline Querétaro & 0 & 1 & 0 & 0 & 1 & 1 & 1 & 5 & 4 & 2 \\
\hline Quintana Roo & 1 & 0 & 0 & 0 & 0 & 0 & 3 & 1 & 3 & 2 \\
\hline San Luis Potosi & 1 & 1 & 1 & 0 & 3 & 1 & 1 & 1 & 2 & 8 \\
\hline Sinaloa & 2 & 4 & 3 & 1 & 4 & 3 & 4 & 2 & 7 & 29 \\
\hline Sonora & 9 & 2 & 8 & 3 & 6 & 16 & 13 & 21 & 44 & 29 \\
\hline Tabasco & 0 & 0 & 1 & 0 & 0 & 0 & 0 & 1 & 6 & 10 \\
\hline Tamaulipas & 0 & 1 & 0 & 1 & 0 & 0 & 1 & 0 & 18 & 20 \\
\hline Tlaxcala & 1 & 0 & 0 & 0 & 2 & 0 & 0 & 1 & 0 & 0 \\
\hline Veracruz & 3 & 3 & 1 & 3 & 2 & 3 & 3 & 11 & 6 & 15 \\
\hline Yucatan & 0 & 0 & 1 & 2 & 13 & 2 & 4 & 5 & 3 & 5 \\
\hline Zacatecas & 0 & 1 & 3 & 2 & 1 & 0 & 3 & 2 & 2 \\
\hline Total & 49 & 43 & 65 & 83 & 113 & 121 & 252 & 372 \\
\hline
\end{tabular}

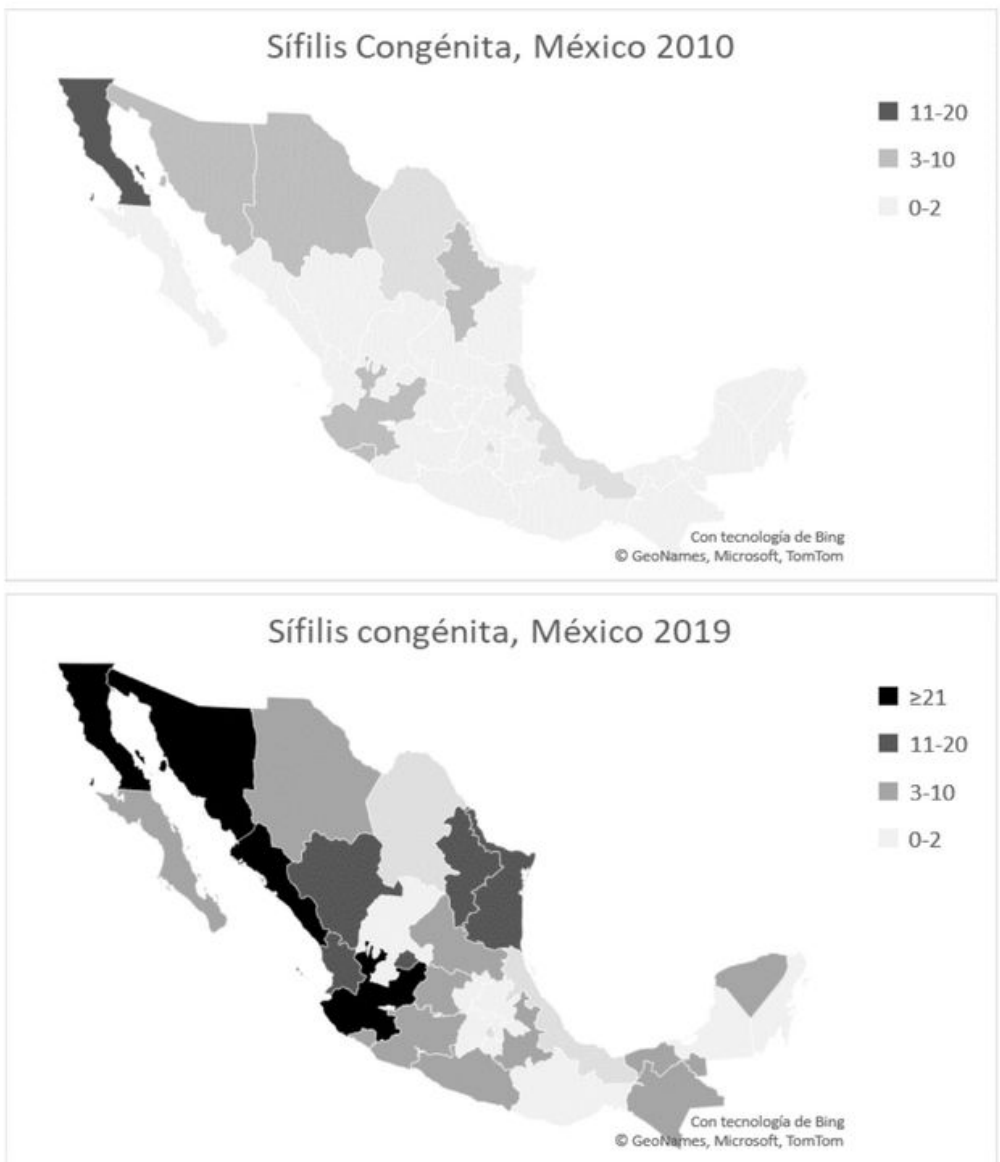

Figure 3

New cases of congenital syphilis by state, Mexico 2010-2019. 


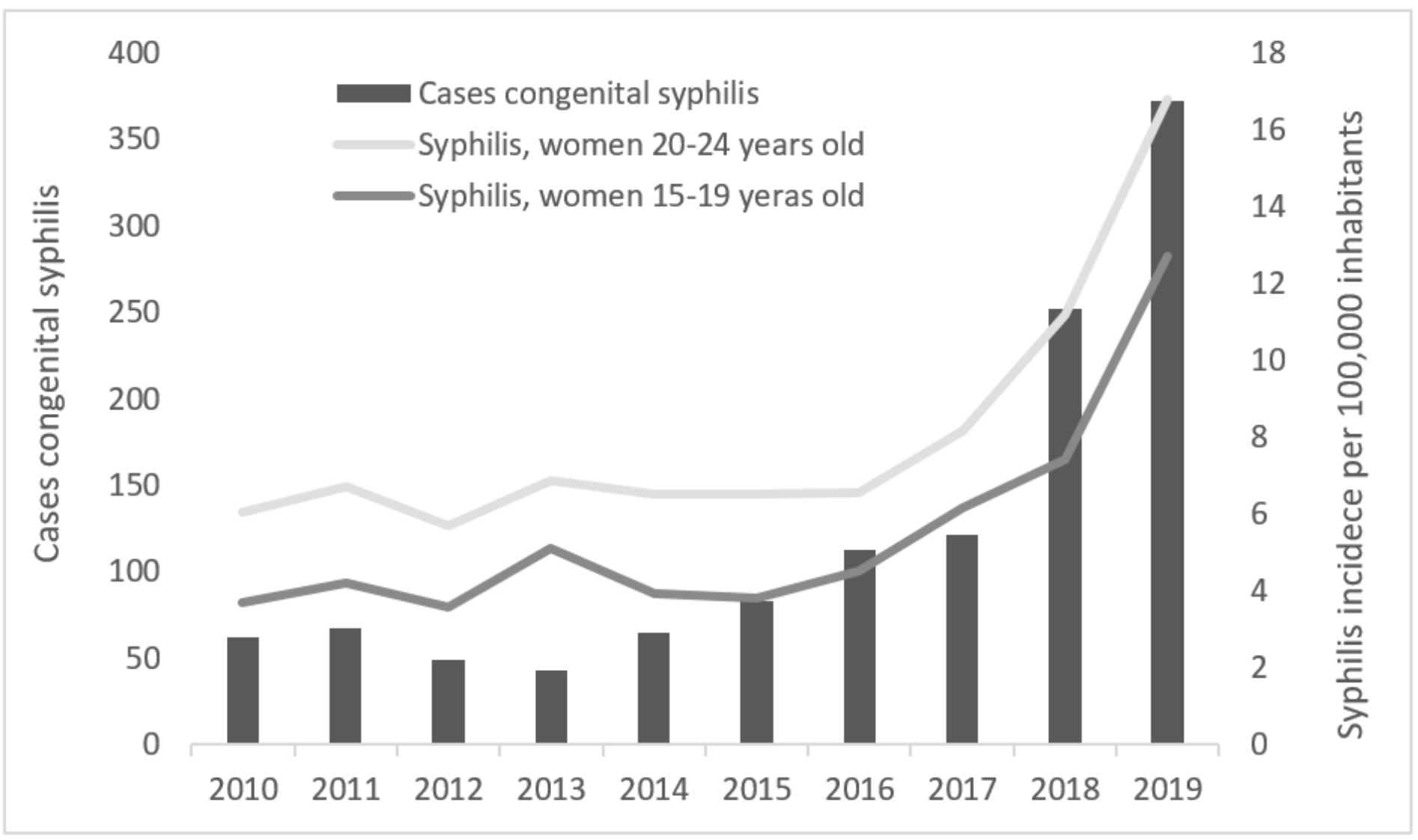

Figure 4

Syphilis among womren aged 15-24 years old and congenital syphilis, Mexico 2010-2019. 


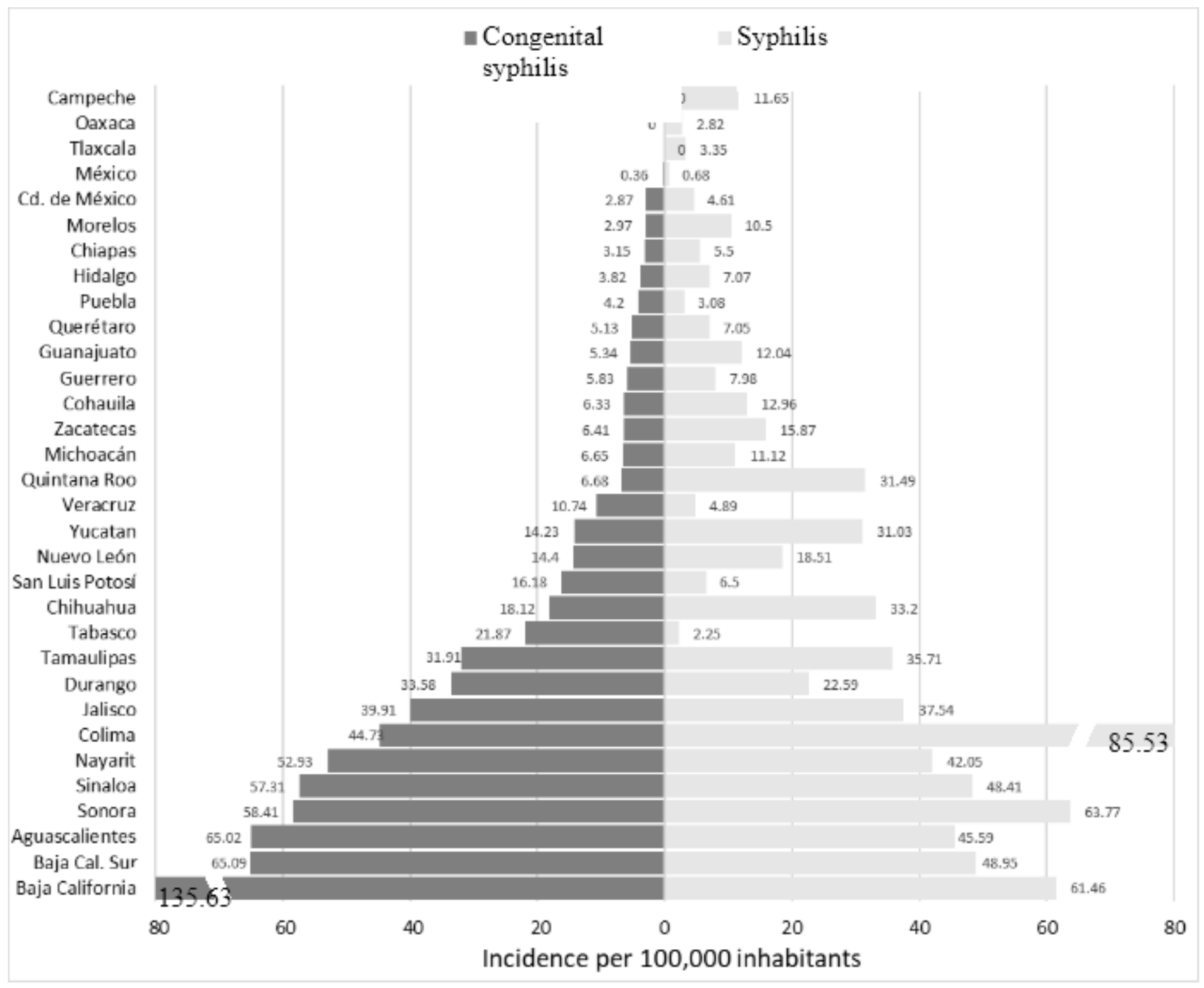

\section{Figure 5}

Syphilis among women 20-24 years old and congenital syphilis, stratified by state of Mexico, year 2019. 